Louisiana State University

LSU Digital Commons

Faculty Publications

Department of Geology and Geophysics

12-10-2009

\title{
Detrital U-Pb zircon dating of lower Ordovician syn-arc-continent collision conglomerates in the Irish Caledonides
}

\author{
Peter D. Clift \\ University of Aberdeen \\ Andrew Carter \\ Birkbeck, University of London \\ Amy E. Draut \\ United States Geological Survey Western Region \\ Hoang Van Long \\ University of Aberdeen \\ David M. Chew \\ Trinity College Dublin
}

See next page for additional authors

Follow this and additional works at: https://digitalcommons.Isu.edu/geo_pubs

\section{Recommended Citation}

Clift, P., Carter, A., Draut, A., Long, H., Chew, D., \& Schouten, H. (2009). Detrital U-Pb zircon dating of lower Ordovician syn-arc-continent collision conglomerates in the Irish Caledonides. Tectonophysics, 479 (1-2), 165-174. https://doi.org/10.1016/j.tecto.2008.07.018

This Article is brought to you for free and open access by the Department of Geology and Geophysics at LSU Digital Commons. It has been accepted for inclusion in Faculty Publications by an authorized administrator of LSU Digital Commons. For more information, please contact ir@lsu.edu. 


\section{Authors}

Peter D. Clift, Andrew Carter, Amy E. Draut, Hoang Van Long, David M. Chew, and Hans A. Schouten 


\section{Detrital U-Pb Zircon Dating of Lower Ordovician Syn-Arc-}

\section{Continent Collision Conglomerates in the Irish Caledonides}

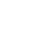

4

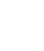

6

(1)
c US Geological Survey, USGS Pacific Science Center, 400 Natural Bridges Drive, a School of Geosciences, University of Aberdeen, Aberdeen, AB24 3UE, UK b School of Earth Sciences, Birkbeck, University of London WC1E 7HX, UK Santa Cruz, CA 95060, USA d Department of Geology, Trinity College Dublin, Dublin 2, Ireland e Woods Hole Oceanographic Institution, Woods Hole, MA 02543,USA 
Erosion in the Irish Caledonides - Clift et al.

24 Formation ( 465 Ma). The dominant source regions lay to the northeast (e.g. in the

25 vicinity of the Ox Mountains, $50 \mathrm{~km}$ distant, along strike). The older portions of the

26 North Mayo Dalradian and its depositional basement (the Annagh Gneiss Complex)

27 do not appear to have been important sources, while the Connemara Dalradian only

28 plays a part after $460 \mathrm{Ma}$, when it supplies the Derryveeny Formation. By this time all

29 erosion from the arc had effectively ceased and exhumation rates had slowed greatly.

30 The Irish Grampian Orogeny parallels the modern Taiwan collision in showing little

31 role for the colliding arc in the production of sediment. Negligible volumes of arc

32 crust are lost because of erosion during accretion to the continental margin.

Keywords: Collision; Erosion; Zircon; Caledonides; Grampian

35

37

\section{Introduction}

Collision events between oceanic island arcs and passive continental margins are an integral part of the Wilson cycle and often precede continent-continent collision events. The process of arc accretion is an essential stage in the building and maintenance of continental crustal volumes because geochemical evidence indicates that most crust is formed in subduction settings (Rudnick, 1995) but that $40 \%$ of the total output is in oceanic arcs that need to be accreted to the continents if it is to be preserved (Clift et al., 2008). As well as accreting crust the collisional orogeny provides a method by which crust may be lost back to the upper mantle because erosion of sediment from the mountains delivers material to subduction trenches and can result in significant crustal loss (von Huene and Scholl, 1991). 
Erosion in the Irish Caledonides - Clift et al.

The patterns of erosion are dependent on the nature of strain accommodation between the arc and the colliding passive margin. Collision of the Indian passive margin with the active margin of Asia in the Eocene seems to have largely driven uplift and erosion of the arc margin (Aitchison et al., 2002; Wu et al., 2007). In contrast, collision between the Luzon Arc and the Chinese passive margin in Taiwan has generated a thrust stack dominated by imbricated passive margin metasedimentary rocks (Suppe, 1981). The accreting arc is exposed as the topographically modest Coast Ranges in the east of the island, which contribute only a fraction of the total modern sediment flux (Dadson et al., 2003). Moreover, provenance analysis of the early syn-collisional sedimentary rocks indicates that these too are largely derived from the reworked passive margin (Dorsey, 1992).

Although the process of arc-continent collision has long been recognized in modern and Neogene oceans (e.g. in Taiwan (Suppe, 1984), in New Caledonia (Aitchison et al., 1995) and Kamchatka (Konstantinovskaia, 2001)), the identification of such processes in the ancient record is less well documented. Good examples are known from the Urals (Brown et al., 2006), but here we focus on the classic example of Connemara in the western Irish Caledonides and the sedimentary record of the collision, as preserved in the South Mayo Trough (Fig. 1). In this study we apply the $\mathrm{U}-\mathrm{Pb}$ dating method to detrital zircon grains extracted from sandstones and conglomerates exposed in the South Mayo Trough to assess the evolving sources of sediment during and after this collisional event. We test the existing models for sediment derivation and settle the debate concerning the relative contributions of the colliding arc and the deformed Laurentian margin to the overall erosion budget.

\section{Regional Setting}


73

74

75

Arc-continent collision in Connemara occurred during the Early Ordovician and is considered to be the cause of the Grampian Orogeny of the British Isles and the Taconic Orogeny in North America (Williams, 1979; Dewey and Shackleton, 1984; Dewey and Ryan, 1990; Stockmal et al., 1990; Cawood and Suhr, 1992; Karabinos et al., 1998; Van Staal et al., 1998). The age of arc-continent collision in western Ireland is presently constrained to $475-465 \mathrm{Ma}$ by the timing of magmatism and peak metamorphism in the Connemara Dalradian terrane, located immediately south of the outcrop of the Rosroe Formation (Cliff et al., 1996; Tanner et al., 1997; Friedrich et al., 1999a). The evolving geochemistry of the colliding Lough Nafooey Arc has been interpreted to indicate "soft collision" (i.e., subduction of the outer passive margin of Laurentia) prior to $480 \mathrm{Ma}$, followed by "hard collision”, i.e., crustal thickening and high-grade metamorphism (Draut and Clift, 2001; Draut et al., 2004; Chew et al., 2007). Orogenic collapse by low-angle detachment faulting occurred after $468 \mathrm{Ma}$ (Wellings, 1998; Clift et al., 2004). The Laurentian margin converted from a passive to an active state, located above a north-dipping subduction zone following the collision. As a result deposition of the sedimentary rocks studied here occurred significantly prior to final suturing of Iapetus in the Early Devonian (McKerrow et al., 1991). This well-defined tectonic framework makes interpretation of the evolving erosion patterns relatively straightforward.

The South Mayo Trough is unusual in being a sedimentary basin located in a suture zone, but without having been disrupted by strong deformation or metamorphism. Although it has been variously interpreted in the past there is now a general consensus that the trough represents the forearc to an intra-oceanic Lough Nafooey Arc (Dewey and Shackleton, 1984). We target three conglomerate units 
Erosion in the Irish Caledonides - Clift et al.

98 deposited in the immediate aftermath of the Grampian Orogeny, the Rosroe

99 Formation, the Derryveeny Conglomerate and the Maumtrasna Formation (Fig. 2).

100 These were deposited in the South Mayo Trough adjacent to the colliding arc and

101 orogen. Deposition of the Rosroe Formation is dated as Early Llanvirn (lower $D$.

102 Artus graptolite zone, 467-464 Ma according to the time scale of Tucker and

103 McKerrow (1995) or 466.2-465 Ma according to the time scale of Cooper and Sadler

104 (2004)). This unit comprises very coarse conglomerates and sandstones, containing

105 abundant granite and volcanic rock clasts (Archer, 1977)(Fig. 3). The Rosroe

106 Formation was interpreted originally to represent the deposits of large submarine fan

107 deltas eroding a volcanic and plutonic arc source south of the modern outcrop

108 (Archer, 1977; Archer, 1984). The Rosroe Formation has been correlated with the

109 Derrylea Formation on the northern limb of the South Mayo Trough (Dewey, 1963;

110 Dewey and Ryan, 1990)(Fig. 2) and eastwards into the Maumtrasna Formation. Up-

111 section, the depositional environment of the South Mayo Trough shallows, 112 culminating in the middle Llanvirn Mweelrea Formation, which comprises a >3-km-

113 thick package of fluvial sandstones derived from the east from a rapidly eroding

114 Dalradian source (Pudsey, 1984).

115 The Derryveeny Conglomerate (Figs. 2 and 3) contains abundant schist and

116 foliated granite clasts, as well as granites similar to those seen in the Rosroe

117 Formation (Graham et al., 1991). The provenance of sediments deposited during

118 exhumation is not uniform, but shows a dominant influx from the east and southeast

119 (Graham et al., 1991; Clift et al., 2002). The late Llanvirn age of sedimentation of the

120 Derryveeny Conglomerate (464-443 Ma) is based on the presence of two clasts,

121 which have yielded Rb-Sr muscovite-whole rock ages of $471 \pm 8 \mathrm{Ma}$ and $462 \pm 7 \mathrm{Ma}$,

122 and the presence of unconformably overlying Lower Silurian strata (Graham et al. 
Erosion in the Irish Caledonides - Clift et al.

123 1991). Additional later Silurian and Devonian strike-slip faulting through Clew Bay

124 also displaced the South Mayo Trough relative to the North Mayo Dalradian (Hutton,

125 1987; Van Staal et al., 1998; Williams, 2002), and some studies have argued for

126 displacements of $>1000 \mathrm{~km}$ along major strike-slip faults in the Caledonides of the

127 British Isles (McKerrow and Elders, 1989). However, the current consensus on the

128 faulting suggests that the amount of displacement was probably not large (Ryan et al., 129 1995).

130

131 Earlier Provenance Work

132

The provenance of the Rosroe Formation was initially constrained to be from

134 south of the present outcrop based on the presence of granite clasts correlated with

135 those known from within the Connemara Dalradian (Archer, 1984). Subsequently

136 trace element and isotopic provenance data show that although these sedimentary

137 rocks were derived from the Laurentian margin (i.e. from the Dalradian) palaeo-

138 current measurements require dominant transport from the northeast, i.e. from the

139 direction of possible sources in the North Mayo Dalradian and Ox Mountains (Fig.

140 1)(Clift et al., 2002; Williams, 2002).

141 The younger Derryveeny Conglomerate has a different clast assemblage and a

142 transport direction froma local Dalradian source located to the southeast; presumably

143 the Connemara Dalradian (Graham et al., 1991; Clift et al., 2002). Graham et al.

144 (1991) therefore proposed that the lack of sediment flux from that direction before

145 sedimentation of the Derryveeny Conglomerate precluded the presence of the

146 Connemara Dalradian in its present location until after that time. 
Erosion in the Irish Caledonides - Clift et al.

148

149

150

151

152

153

154

155

156

157

158

159

160

161

162

163

164

165

166

167

168

169

170

171

\section{Analytical Strategy}

The Rosroe Formation was sampled on the southern shore of Killary Harbour, $1.5 \mathrm{~km}$ from the centre of Leenane village at $53^{\circ} 35.9^{\prime} \mathrm{N}, 9^{\circ} 43.6^{\prime} \mathrm{W}$ (Irish grid reference L 85706, 62434). The Maumtrasna Formation was sampled by the roadside in the Partry Mountains at $53^{\circ} 39.7^{\prime} \mathrm{N}, 9^{\circ} 23.9^{\prime} \mathrm{W}$ (M 07660, 68958). The Derryveeny Conglomerate was sampled on the shore of Lough Mask at $53^{\circ} 35.8^{\prime} \mathrm{N} 9^{\circ} 26.1^{\prime} \mathrm{W}$ (M 05057, 61797). The sediments are all coarse grained, apparently proximal deposits. Samples for U-Pb dating were analysed by laser ablation-inductively coupled plasma mass spectrometer (LA-ICPMS) using a New Wave 213 aperture imaged frequency quintupled laser ablation system $(213 \mathrm{~nm})$ coupled to an Agilent 750 quadrupole-based ICP-MS at University College, London. Real time data were processed using GLITTER ${ }^{\mathrm{TM}}$. Repeated measurements of external zircon standard Plesovic (reference age determined by thermal ionisation mass spectrometry (TIMS)

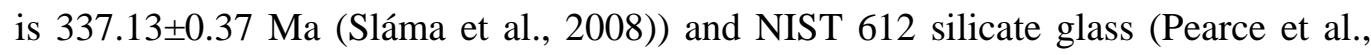
1997) were used to correct for instrumental mass bias and depth-dependent interelement fractionation of $\mathrm{Pb}$, Th and $\mathrm{U}$. Data were filtered using standard discordance tests with a $10 \%$ cut-off.

The ${ }^{206} \mathrm{~Pb} /{ }^{238} \mathrm{U}$ ratio was used to determine ages less than $1000 \mathrm{Ma}$ and the ${ }^{207} \mathrm{~Pb} /{ }^{206} \mathrm{~Pb}$ ratio for grains older than $1000 \mathrm{Ma}$. Common $\mathrm{Pb}$ was determined by the ${ }^{208} \mathrm{~Pb}$ method assuming a common $\mathrm{Pb}$ composition from the age-dependent $\mathrm{Pb}$ model of Cumming and Richards (1975). Data were processed using Isoplot ${ }^{\mathrm{TM}}$ (Ludwig, 2003). Uncertainties are typically in the range 1 to $3 \%$ and are shown for each analysis in Table 1. Around 100 grains were analyzed from each unit in order to 
Erosion in the Irish Caledonides - Clift et al.

172 provide a statistically robust image of what is potentially a complex source terrain,

173 following the recommendations of Ruhl and Hodges (2005).

174

175 Results

176

The results of our analysis are given in Table 1 and are graphically displayed as probability density plots in Figure 4 . These data can be compared with the known ranges of zircons in different parts of the Dalradian Supergroup, as well as the Moine Supergroup and the unmetamorphosed Torridonian Group, which characterize the

181 Laurentian margin in the British Isles, and are thus potentially sources of sediment to 182 the South Mayo Trough (Fig. 5). The age of the potential arc sources can be 183 constrained to be older than the age of the Grampian Orogeny (the end of subduction 184 volcanism)(Dewey and Mange, 1999) and younger than the proposed Tremadoc 185 subduction initiation at 495 Ma (Clift and Ryan, 1994; Chew et al., 2007). 186 Comparison with the source ages helps to define and quantify the erosional flux from 187 these different ranges.

188 The detrital grain ages in all three samples show clustering into roughly 189 defined populations. There is a well defined younger grouping of 400-600 Ma, but no 190 grains lie between $\sim 600-750$ Ma. The single most numerous population lies between 191 900-1300 Ma, which correlates with the well characterized Grenville Orogeny in 192 eastern North America (McLelland et al., 1996), as well as parts of the British Isles 193 (Brook et al., 1976; Daly, 1996). A third grouping is dated at 1300-2000 Ma. These 194 ages correlate with zircons previously dated in the Dalradian Supergroup (Cawood et 195 al., 2003). The Dalradian zircons have in turn been reworked from original crystalline 196 sources that have been correlated to a number of smaller orogenic belts in eastern 
Erosion in the Irish Caledonides - Clift et al.

197 Canada, namely the Torngat, New Quebec and Nagssugtoqidian (Scott, 1998;

198 Whitehouse et al., 1998; Wardle et al., 2002). There are very few grains in our

199 samples dating between 2.0 and $2.5 \mathrm{Ga}$, but an older population of ages greater than

$200 \quad 2.5 \mathrm{Ga}$ is common and correlates to ages known from the Lewisian Complex of NW

201 Scotland and other parts of the Superior Craton of North America (Whitehouse et al., 202 1997; Corfu et al., 1998).

203 All three samples show a relatively modest proportion of younger grains that 204 could have been eroded from the colliding Lough Nafooey Arc, comprising 205 approximately 20\%, 6\% and 12\% respectively in the Rosroe, Maumtrasna and 206 Derryveeny Formations. The Maumtrasna Formation in particular is dominated by 207 erosional flux from the Laurentian margin. Nonetheless, a number of coherent and 208 significant differences are seen between the formations. The proportion of grains 209 older than 2.0 Ga grains is fairly constant, but the Derryveeny Formation has the 210 highest proportion of 1.3-2.0 Ga grains. In contrast, the Maumtrasna has the highest 211 proportion (47\%) of 800-1300 Ma grains.

212

\section{Discussion}

214

215 Sediment Sources

The new zircon data confirm the hypothesis that the vast majority of the 218 sediment flux into the South Mayo Trough following the Grampian Orogeny was 219 derived by erosion from the Laurentian margin, not from the colliding arc (Clift et al., 220 2002). The data also permit the source of the Laurentian debris to be constrained by 221 comparison with the known ages of the Dalradian, Moine and Torridonian 
Erosion in the Irish Caledonides - Clift et al.

222 Supergroup rocks (Fig. 5). The situation in western Ireland is potentially more

223 complex than for many such suture zone basins because the South Mayo Trough is

224 bordered both north and south by fragments of Laurentian crust (Fig. 1).

225 The Connemara and North Mayo Dalradian metamorphic terranes are 226 considered to be metamorphosed fragments of the Laurentian margin (Lambert and 227 McKerrow, 1976; Dewey and Shackleton, 1984; Harris et al., 1994). Connemara is 228 inferred to be displaced from its original location and lies south of the units that 229 comprise the Lough Nafooey Island Arc. This displacement cannot be the result of 230 southward thrusting of high-grade metamorphic Connemara over South Mayo 231 because much of this has never exceeded anchizone metamorphic conditions, 232 although it is possible that Connemara might have been underthrust under the South 233 Mayo Trough. The conventional explanation for the enigmatic position of Connemara 234 today is that this was achieved by post-Grampian strike-slip tectonism that affected 235 the Laurentian margin (e.g., the Southern Uplands Fault, the Fair Head-Clew Bay 236 Line (equivalent to the Highland Boundary Fault in Scotland) and the Great Glen 237 Fault (Hutton, 1987)).

238 The units comprising the Connemara Dalradian have been correlated to the 239 upper parts of the type sections in the Scottish Highlands, i.e. the Southern Highland 240 and Argyll Groups, with the lowermost Clifden Schist lying in the upper Appin Group 241 (Leake and Tanner, 1994; Chew, 2001)(Table 2). In contrast, the lower parts of the 242 supergroup dominate the North Mayo Dalradian exposure. Argyll Group rocks are 243 seen, but Appin and Grampian Groups dominate and even the underlying Annagh 244 Gneiss Complex (probable sub-Dalradian crystalline basement, similar to the Moine 245 Supergroup) is identified (Daly, 1996). However, erosion has likely removed 246 significant volumes of younger Argyll Group that would have covered the present 
Erosion in the Irish Caledonides - Clift et al.

exposure, although no Southern Highland Group is known from the structurally highest units under the Achillbeg Fault (Fig. 1).

The presence of pre-2.0 Ga grains in all three formations demonstrates that a purely Grampian Group or Moine/Annagh source is unlikely, as these ages are very rare in those units (Cawood et al., 2007). The numerous 800-1300 Ma population in all the conglomerates, and especially the Maumtrasna, is most characteristic of the Southern Highland and Argyll Groups (Cawood et al., 2003), implying preferential erosion of the upper part of the Dalradian into the South Mayo Trough. Consequently this argues against North Mayo being the primary source of Laurentian detritus, although we do recognize that erosion from North Mayo could have removed much of the younger material there. While erosion from Connemara would most readily explain the age population in the Derryveeny Formation, this is harder to apply to the Rosroe and Maumtrasna Formations because of the palaeo-current constraints.

We suggest that the Ox Mountains located around $50 \mathrm{~km}$ to the northeast, or equivalents in that region now buried by Carboniferous sedimentary rocks, might be appropriate sources because they are relatively local and expose mostly Southern Highland and Argyll Group rocks (Alsop and Jones, 1991). Sediment transport from that direction is also consistent with the SW-ward palaeo-current directions, which also argue against orthogonal sediment flux from North Mayo (Archer, 1984; Clift et al., 2002). We favour erosion from sources in the Ox Mountain/central Ireland region rather than Dalradian units now exposed in Scotland because of the coarse grain size of the conglomerates. Zircon ages alone cannot rule out the Scottish Dalradian as a source to the South Mayo Trough but the $350 \mathrm{~km}$ minimum transport distance does suggest that this is unlikely for the proximal facies observed. These regions could be sources to finer grained sedimentary rocks in the basin, or if strike-slip faulting had 
Erosion in the Irish Caledonides - Clift et al.

272 moved the South Mayo Trough far relative to the Dalradian since sedimentation,

273 which is considered unlikely (Ryan et al., 1995). It is noteworthy that the $\sim 820-670$

274 Ma "Knoydartian” ages recorded in parts of the SW Scottish Highlands (Friend et al.,

275 1997; Tanner and Evans, 2003) are not found in the Mayo Conglomerates, consistent

276 with a more local provenance.

277

278 Grenville Sources?

279

Although the U-Pb dating of zircons does significantly constrain the

provenance of the Lower Ordovician conglomerates and sandstones other data sets

need to be considered for a more integrated and coherent image of orogenic erosion.

283 By themselves the U-Pb ages suggest a dominantly Dalradian metamorphic

284 provenance, yet the prevalence of granitoid clasts and of apatite grains would suggest

285 strong influx from an igneous source. Heavy mineral studies show that the zircon

286 populations in the Rosroe and Maumtrasna Formations comprise around 50\%

287 euhedral or subhedral grains, which are not typical of erosion from a metasedimentary

288 source (Dewey and Mange, 1999). If these grains are not dominantly from the

289 colliding arc, as might be expected, then their ages would suggest Grenville igneous

290 sources, potentially in the foreland of the Grampian orogeny. A direct link to the

291 Grenville in the Grampian foreland is hard, although potentially transport is only 100-

$292150 \mathrm{~km}$ across strike. This is because sediment flux from these sources would have to

293 cross the core of the Grampian orogeny. However, this is not impossible, because

294 major rivers are known to cut across active mountains, e.g. , the Sutlej River and

295 Himalaya, yet these are not common features and are not known from modern arc-

296 continent collisional orogens. 
Erosion in the Irish Caledonides - Clift et al.

Igneous sources with the characteristic 900-1300 Ma ages are known from the Gardar Province of southern Greenland (Blaxland et al., 1978), although Grenville age sources from East Greenland are generally too old to make good matches for the grains seen in South Mayo (Kalsbeek et al., 2000). The texturally immature and coarse-grained nature of the sediment argues against erosion from far distant sources, while the palaeo-flow direction from the ENE makes erosion from the classic North American Grenville exposures impossible (Fig. 1)(Hoffman, 1989; Rivers, 1997). A clear resolution of this enigma is not currently apparent. Nonetheless, we presently favour a dominant reworking of Grenville igneous zircons through the Dalradian metasedimentary sequences, with a mostly local provenance from the ENE, supported by the sedimentary facies and the U-Pb age data.

\section{Ordovician Grains}

The youngest grain population in each of the units warrants further inspection in order to assess a possible arc source. Figure 7 shows the age spectrum for the 450 600 Ma time span, with the major tectonic events known from the region marked to provide context. The diagram highlights the short time lag (and potentially rapid exhumation) between zircon crystallization and sedimentation for the Maumtrasna and Rosroe Formations. However, if the zircon grains were volcanic and not plutonic then the short time lag would not be significant in limiting exhumation rates. Zircons in the Maumtrasna and Rosroe Formations correlate in age with syn-collisional plutons in Connemara (Tanner et al., 1997; Friedrich et al., 1999b) and confirm some erosion of arc debris into the South Mayo Trough. However, the Derryveeny Formation grains are resolvably older, peaking around $540 \mathrm{Ma}$ (cf., $470 \mathrm{Ma}$ ), close to 
Erosion in the Irish Caledonides - Clift et al.

322 the end of extension on the Laurentian margin and the onset of seafloor spreading

323 (McKerrow et al., 1991; Cawood et al., 2001). Critically, these pre-date the apparent

324 initiation of subduction in the Iapetus and so cannot be linked to an early phase of

325 intra-oceanic arc magmatism. Few granites of this age are known from the Dalradian,

326 with the nearest suitable known sources being the “Older Granites” of Barrow (1893),

327 generally dating around 600 Ma (Oliver et al., 2008), but with some as young as 588

328 Ma in Scotland (Braeval Granite) (Kinny et al., 2003). Rift-related magmatism dating

329 to as young as $550 \mathrm{Ma}$ is however known from the Newfoundland sector of the

330 Laurentian margin (Cawood et al., 2001). We thus interpret these grains to represent

331 erosion from intrusions linked to break-up of the Laurentian margin and not to the

332 colliding arc, because they predate the generally accepted age of subduction initiation

333 and are synchronous with break-up, albeit younger than any granite so far dated. We

334 suggest that by Derryveeny times erosion from the colliding arc had ceased entirely.

335 Most likely the extension and subsidence that occurred at the time of orogenic

336 collapse and subduction polarity reversal (post-470 Ma) would have buried or

337 submerged any residual topography.

338

339 Age of Sedimentation

340

The new $\mathrm{U}-\mathrm{Pb}$ ages provide some control on the age of sedimentation. The

342 Rosroe Formation is dated at 464-467 Ma based on graptolites (Graham et al., 1989),

343 which is consistent with the youngest zircon grain age of $465 \pm 9.9 \mathrm{Ma}$. The short time

344 delay of no more than 11 m.y. between zircon crystallization and sedimentation

345 implies rapid exhumation rates. Sedimentation of the Derryveeny Conglomerate is

346 dated loosely as being post Llanvirn and pre-Llandovery (Graham et al., 1989)(i.e., 
Erosion in the Irish Caledonides - Clift et al.

460-443 Ma) while the youngest grain is dated at $512 \pm 10 \mathrm{Ma}$. This implies much slower rates of long-term exhumation by Derryveeny times, assuming that the zircons are not of volcanic origin.

The youngest grain dated from the Maumtrasna Formation yields an age of $452.3 \pm 6 \mathrm{Ma}$, which is younger than the Llanvirn depositional age (464-465 Ma) most recently assigned by Graham (1987). The age of the Maumtrasna Formation has been controversial, with ages ranging from Llandeilo, Caradoc and even Devonian being proposed (Williams, 1972; Max et al., 1978; Williams, 1980). Mapping by Graham (1987) however demonstrated that the Maumtrasna Formation underlies the Glenummera Formation (Fig. 2). This in turn is dated as being deposited during the Llanvirn, no later than 463.6 Ma according to the graptolite assignment of Harper et al. (1988), as applied to the more recent timescale of Cooper and Sadler (2004). However, this particular grain age is around 13\% discordant and cannot be used as an accurate constraint on the age of crystallization or sedimentation of the Maumtrasna Formation, beyond being a young “arc-like” rather than Dalradian grain.

\section{Conclusions}

units in the South Mayo Trough allow models for erosion during and after the Grampian Orogeny to be tested. As in Taiwan erosion during the peak orogenic and early collapse phase of arc collision is dominated by erosion from the deformed and metamorphosed passive margin, not the colliding arc. Grain ages that lie close to the depositional ages confirm suggestions of rapid exhumation at that time (Friedrich et al., 1999a; Power et al., 2001). However, our grain populations, together with the 
Erosion in the Irish Caledonides - Clift et al.

372 SSW-directed palaeo-currents indicate that during deposition of the Maumtrasna and

373 Rosroe Formations the dominant flux of material was along strike from the Ox

374 Mountains or similar ranges to the northeast, not orthogonally into the basin from the

375 Connemara Dalradian. In this respect sediment dispersal mirrors patterns seen in

376 modern arc collision zones, such as Taiwan. After 460 Ma when the Derryveeny

377 Formation was deposited erosion is completely of Laurentian provenance and is

378 consistent with erosion from the Connemara Dalradian. Exhumation rates appear to

379 have fallen rapidly by this time. The North Mayo Dalradian does not appear to have

380 been an important source of sediment to this particular basin, but could have supplied

381 material along strike, presumably to equivalent basins located to the southwest.

382 Erosion from the colliding arc is generally modest and suggests that very little arc

383 crust is destroyed during its accretion to the Laurentian margin.

384

385

386 Acknowledgements

387 We thank the College of Physical Sciences at the University of Aberdeen for support

388 for this project. Grahame Oliver and Bernard Leake are thanked for their advice about

389 the Dalradian. PC thanks the Geological Society of London for their support in

390 attending the IGCP meeting in Tainan, Taiwan. Paul Ryan and Peter Cawood are

391 thanked for the helpful reviews used in improving the original manuscript. 
Erosion in the Irish Caledonides - Clift et al.

394

395

396

397

398

399

400

401

402

403

404

405

406

407

408

409

410

411

412

413

414

415

416

417

\section{Figure Captions}

Figure 1. Regional geological map of western Ireland showing the Connemara and North Mayo metamorphic terranes separated by the South Mayo volcanic island arc terrane. The strike-slip faulted boundary between the Connemara and South Mayo terranes is buried under Silurian strata, while the Achill Beg Fault separates low grade arc and trench rocks of South Mayo from the high grade rocks of North Mayo. Sample locations are shown with a star.Inset maps show (1) the location of the Grenville Province in North America (Hoffman, 1989) and (2) the location of the study area within the British Isles,

Figure 2. Schematic stratigraphy of the South Mayo Trough Ordovician, showing the variability from south to north limb of the syncline and time equivalent units. A star marks sampled units.

Figure 3. Field photographs of the outcrops sampled in this study (A) Rosroe Formation in Killary Harbour, 1 km west of Leenane, (B) Derryveeny Conglomerate on shores of Lough Mask, and (C) Maumtrasna Formation on side of road in Partry Mountains, northwest of Tourmakeady. See Figure 1 for locations. Detailed grid coordinates are provided in the text.

Figure 4. Probability density plots of the U-Pb ages of detrital zircon grains separated from each of the studied formations. Lowermost panel shows averaged age plots for the upper and lower parts of the Dalradian Supergroup, respectively the Southern 
Erosion in the Irish Caledonides - Clift et al.

418 Highland Group (Cawood et al., 2003) and the Grampian Group (Cawood et al., 2003;

419 Banks et al., 2007).

420

421 Figure 5. Probability density plots of the U-Pb ages of zircon grains taken from the

422 various possible source terrains within Laurentia close to the South Mayo Trough.

423 Ages of the Moine Supergroup are from Friend et al. (2003) and Cawood et al. (2003;

424 2004). The Upper Dalradian ages (Southern Highland Group) are from Cawood et al.

425 (2003). Middle Dalradian (Appin and Argyll Groups) are from Loewy et al. (2003)

426 and Cawood et al. (2003). Lower Dalradian (Grampian Group) ages are from Cawood

427 et al. (2003) and Banks et al. (2007). Torridonian ages are from Rainbird et al. (2001).

428

429 Figure 6. Pie diagrams showing the relative proportions of the different major age 430 populations within each of the samples analyzed.

431

432 Figure 7. Probability density plots of the U-Pb ages of detrital zircon grains between

433450 and 600 Ma. Ages of the Connemara gabbros are from Friedrich et al. (1999b).

434 Age of the Oughterard Granite is from Tanner et al. (1997) and Friedrich et al.

435 (1999b). Age of the Portsoy and Keith Granites are personal communications (J.

436 Mendum in Strachan et al. (2002)). Age of the Carn Chuinneag granite is from Oliver

437 et al. (2008).

438

439 Table 1. U-Pb isotopic analytical data for the zircon grains analysed in this study.

440 
Erosion in the Irish Caledonides - Clift et al.

441 Table 2. Summary chart showing the major units of the Dalradia stratigraphy exposed

442 in the vicinity of the South Mayo Trough. Data compiled from Geological Survey of

443 Ireland, sheet 11 memoir.

444

445 
Erosion in the Irish Caledonides - Clift et al.

\section{References}

Aitchison, J.C., Clarke, G.L., Meffre, S. and Cluzel, D., 1995. Eocene arc-continent collision in New Caledonia and implications for regional south-west Pacific tectonic evolution. Geology 23, 161-164.

Aitchison, J.C., Davis, A.M., Badengzhu and Luo, H., 2002. New constraints on the India-Asia collision: The lower Miocene Gangrinboche conglomerates, Yarlung Tsangpo suture zone, SE Tibet. J. Asian Earth Sci. 21, 253-265.

Alsop, G.I. and Jones, C.S., 1991. A review and correlation of Dalradian stratigraphy in the southwest and central Ox Mountains and southern Donegal, Ireland. Irish J. Earth Sci. 11(1), 99-112.

Archer, J.B., 1977. Llanvirn stratigraphy of the Galway-Mayo border area, western Ireland. Geol. J. 12, 77-98.

Archer, J.B., 1984. Clastic intrusions in deep-sea fan deposits of the Rosroe Formation, Lower Ordovician, western Ireland. J. Sed. Petrol. 54, 1197-1205.

Banks, C.J., Smith, M., Winchester, J.A., Horstwood, M.S.A., Noble, S.R. and Ottley, C.J., 2007. Provenance of intra-Rodinian basin fills; the lower Dalradian Supergroup, Scotland. Precamb. Res. 153(1-2), 46-64.

Barrow, G., 1893. On the intrusion of muscovite biotite gneiss in the southeast Highlands of Scotland and its accompanying metamorphism. Quarterly Journal of the Geological Society of London 49, 330-358.

Blaxland, A.B., Breemen, O.v., Emeleus, C.H. and Anderson, J.G., 1978. Age and origin of the major syenite centers in the Gardar Province of South Greenland: Rb-Sr studies. Geol. Soc. Am. Bull. 89, 231-244.

Brook, M., Brewer, M.S. and Powell, D., 1976. Grenville age for rocks in the Moine of north-western Scotland. Nature 260(5551), 515-517.

Brown, D., Puchkov, V., Alvarez-Marron, J., Bea, F. and Perez-Estaun, A., 2006. Tectonic processes in the Southern and Middle Urals; an overview. In: D.G. Gee and R.A. Stephenson (Eds.), European lithosphere dynamics, 32, pp. 407419.

Cawood, P.A., McCausland, P.J.A. and Dunning, G.R., 2001. Opening Iapetus: Constraints from the Laurentian margin in Newfoundland. Geol. Soc. Am. Bull. 113, 443-453.

Cawood, P.A., Nemchin, A.A., Smith, M. and Loewy, S., 2003. Source of the Dalradian Supergroup constrained by U-Pb dating of detrital zircon and implications for the East Laurentian margin. J. Geol. Soc., Lond. 160(2), 231246.

Cawood, P.A., Nemchin, A.A., Strachan, R.A., Kinny, P.D. and Loewy, S., 2004. Laurentian provenance and an intracratonic tectonic setting for the Moine Supergroup, Scotland, constrained by detrital zircons from the Loch Eil and Glen Urquhart successions. J. Geol. Soc., Lond. 161(5), 861-874.

Cawood, P.A., Nemchin, A.A., Strachan, R.A., Prave, A.R. and Krabbendam, M., 2007. Sedimentary basin and detrital zircon record along East Laurentia and Baltica during assembly and breakup of Rodinia. J. Geol. Soc., Lond. 164, 257-275.

Cawood, P.A. and Suhr, G., 1992. Generation and obduction of ophiolites: constraints from the Bay of Islands Complex, western Newfoundland. Tectonics 11, 884897. 
Erosion in the Irish Caledonides - Clift et al.

494

495

496

497

498

499

500

501

502

503

504

505

506

507

508

509

510

511

512

513

514

515

516

517

518

519

520

521

522

523

524

525

526

527

528

529

530

531

532

533

534

535

536

537

538

539

540

541

542

543

Chew, D.M., 2001. Basement protrusion origin of serpentinite in the Dalradian. Irish J. Earth Sci. 19, 23-35.

Chew, D.M., Graham, J.R. and Whitehouse, M.J., 2007. U-Pb zircon geochronology of plagiogranites from the Lough Nafooey (= Midland Valley) arc in western Ireland: constraints on the onset of the Grampian orogeny. J. Geol. Soc. Lond. 164, 747-750.

Cliff, R.A., Yardley, B.W.D. and Bussy, F.R., 1996. U-Pb and Rb-Sr geochronology of magmatism and metamorphism in the Dalradian of Connemara, western Ireland. J. Geol. Soc. Lond. 153, 109-120.

Clift, P.D., Dewey, J.F., Draut, A.E., Chew, D.M., Mange, M. and Ryan, P.D., 2004. Rapid tectonic exhumation, detachment faulting and orogenic collapse in the Caledonides of western Ireland. Tectonophysics 384(1-4), 91-113.

Clift, P.D., Draut, A.E., Hannigan, R., Layne, G. and Blusztajn, J., 2002. Trace element and $\mathrm{Pb}$ isotopic constraints on the provenance of the Rosroe and Derryveeny Formations, south Mayo, Ireland. Trans. R. Soc. Edin. Earth Sci. 93, Part 2, 101-110.

Clift, P.D. and Ryan, P.D., 1994. Geochemical evolution of an Ordovician Island Arc, South Mayo, Ireland. J. Geol. Soc. Lond. 151, 329-342.

Clift, P.D., Schouten, H. and Vannucchi, P., 2008. Arc-Continent Collisions, Subduction Mass Recycling and the Maintenance of the Continental Crust. In: P. Cawood and A. Kroener (Eds.), Accretionary Orogens in Space and Time, in press.

Cooper, R.A. and Sadler, P.M., 2004. The Ordovician Period. In: F.M. Gradstein, J.G. Ogg and A.G. Smith (Eds.), A Geologic Time Scale 2004, pp. 165-187.

Corfu, F., Crane, A., Moser, D. and Rogers, G., 1998. Pb zircon systematics of Gruinard Bay, Northwest Scotland; implications for the early orogenic evolution of the Lewisian Complex. Contrib. Min. Petrol. 133(4), 329-345.

Cumming, G.L. and Richards, J.R., 1975. Ore lead isotope ratios in a continuously changing Earth. Earth Planet. Sci. Lett. 28, 155-171.

Dadson, S. et al., 2003. Links between erosion, runoff variability and seismicity in the Taiwan orogen. Nature 426, 648-651.

Daly, J.S., 1996. Pre-Caledonian history of the Annagh gneiss complex, north-western Ireland, and correlation with Laurentia-Baltica. Irish J. Earth Sci. 15, 5-18.

Dewey, J.F., 1963. The lower Palaeozoic stratigraphy of central Murrisk, County Mayo, Ireland, and the evolution of the South Mayo Trough. Quat. J. Geol. Soc. Lond. 119, 313-344.

Dewey, J.F. and Mange, M., 1999. Petrology of Ordovician and Silurian sediments in the Western Irish Caledonides: tracers of short-lived Ordovician continent-arc collision orogeny and the evolution of the Laurentian Appalachian-Caledonian margin. In: C. MacNiocaill and P.D. Ryan (Eds.), Continental Tectonics. Geol. Soc. Lond., Spec. Publ., 164, pp. 55-107.

Dewey, J.F. and Ryan, P.D., 1990. The Ordovician Evolution of the South Mayo Trough, western Ireland. Tectonics 9, 887-901.

Dewey, J.F. and Shackleton, R.M., 1984. A model for the evolution of the Grampian tract in the early Caledonides and Appalachians. Nature 312, 115-121.

Dorsey, R.J., 1992. Collapse of the Luzon volcanic arc during onset of arc-continent collision; evidence from a Miocene-Pliocene unconformity, eastern Taiwan. Tectonics 11, 177-191.

Draut, A.E. and Clift, P.D., 2001. Geochemical evolution of arc magmatism during arc-continent collision, South Mayo, Ireland. Geology 29(6), 543-546. 
Draut, A.E., Clift, P.D., Chew, D.M., Cooper, M.J., Taylor, R.N. and Hannigan, R.E., 2004. Laurentian crustal recycling in the Ordovician Grampian Orogeny; Nd isotopic evidence from western Ireland. Geol. Mag. 141(2), 195-207.

Friedrich, A.M., Bowring, S.A., Martin, M.W. and Hodges, K.V., 1999a. Short-lived continental magmatic arc at Connemara, western Irish Caledonides; implications for the age of the Grampian Orogeny. Geology 27(1), 27-30.

Friedrich, A.M., Hodges, K.V., Bowring, S.A. and Martin, M.W., 1999b. Geochronological constraints on the magmatic, metamorphic and thermal evolution of the Connemara Caledonides, western Ireland. J. Geol. Soc., Lond. 156, 1217-1230.

Friend, C.R.L., Kinny, P.D., Rogers, G., Strachan, R.A. and Paterson, B.A., 1997. U$\mathrm{Pb}$ zircon geochronological evidence for Neoproterozoic events in the Glenfinnan Group (Moine Supergroup): the formation of the Ardgour gneiss, northwest Scotland. Contrib. Min. Petrol. 128, 101-113.

Friend, C.R.L., Strachan, R.A., Kinny, P.D. and Watt, G.R., 2003. Provenance of the Moine Supergroup of NW Scotland: evidence from geochronology of detrital and inherited zircons from (meta)sedimentary rocks, granites and migmatites. J. Geol. Soc. Lond. 160, 247-257.

Graham, J.R., 1987. The nature and field relations of the Ordovician Maumtrasna Formation, County Mayo Ireland. Geol. J. 22, 347-369.

Graham, J.R., Leake, B.E. and Ryan, P.D., 1989. The geology of South Mayo, western Ireland. University of Glasgow.

Graham, J.R., Wrafter, J.P., Daly, J.S. and Menuge, J.F., 1991. A local source for the Ordovician Derryveeny Formation, western Ireland: implications for the Connemara Dalradian. In: A.C. Morton, S.P. Todd and P.D.W. Haughton (Eds.), Developments in Sedimentary Provenance Studies. Geol. Soc. Lond., spec. publ., 57, pp. 199-213.

Harper, D.A.T., Graham, J.R., Owen, A.W. and Donovan, S.K., 1988. An Ordovician fauna from Lough Shee, Partry Mountains, Co. Mayo, Ireland. Geol. J. 23(4), 293-310.

Harris, A.L. et al., 1994. The Dalradian Supergroup in Scotland, Shetland and Ireland. In: W. Gibbons and A.L. Harris (Eds.), A Revised Correlation of Precambrian Rocks in the British Isles. Geol. Soc., Lond. Spec. Rpt., 22, pp. 33-53.

Hoffman, P.F., 1989. Precambrian geology and tectonic history of North America. In: A.W. Bally and A.R. Palmer (Eds.), The Geology of North America-An Overview, pp. 447-511.

Hutton, D.H.W., 1987. Strike-slip terranes and a model for the evolution of the British and Irish Caledonides. Geol. Mag. 124, 405-425.

Kalsbeek, F., Thrane, K., Nutman, A.P. and Jepsen, H.F., 2000. Late Mesoproterozoic to early Neoproterozoic history of the East Greenland Caledonides: evidence for Grenvillian orogenesis? J. Geol. Soc. Lond. 157(6), 1215-1225.

Karabinos, P., Samson, S.D., Hepburn, J.C. and Stoll, H.M., 1998. Taconian orogeny in the New England Appalachians; collision between Laurentia and the Shelburne Falls arc. Geology 26, 215-218.

Kinny, P.D., Strachan, R.A., Kocks, H. and Friend, C.R.L., 2003. U-Pb geochronology of late Neoproterozoic augen granites in the Moine Supergroup, NW Scotland; dating of rift-related, felsic magmatism during supercontinent break-up? J. Geol. Soc., Lond. 160(6), 925-934. 
601

602

603

604

605

606

607

608

609

610

611

612

613

614

615

616

617

618

619

620

621

622

623

624

625

626

627

628

629

630

631

632

633

634

635

636

637

638

639

640

Konstantinovskaia, E.A., 2001. Arc-continent collision and subduction polarity reversal in the Cenozoic evolution of the Northwest Pacific: an example from Kamchatka. Tectonophysics 333, 75-94.

Lambert, R.S.J. and McKerrow, W.S., 1976. The Grampian Orogeny. Scott. J. geol. 12, 271-292.

Leake, B.E. and Tanner, P.W.G., 1994. The geology of the Dalradian and associated rocks of Connemara, western Ireland. Memoir. Royal Irish Academy, Dublin, $96 \mathrm{pp}$.

Loewy, S.L., Connelly, J.N., Dalziel, I.W.D. and Gower, C.F., 2003. Eastern Laurentia in Rodinia: constraints from whole-rock $\mathrm{Pb}$ and $\mathrm{U} / \mathrm{Pb}$ geochronology. Tectonophysics 375, 169-197.

Ludwig, K., 2003. Isoplot 3.0. Special Publication, 4, Berkeley Geochronology Center.

Max, M.D., Kelly, T.J. and Morris, W.A., 1978. The Maumtrasna Group problem: possible Devonianrocks in Murrisk, western Ireland. J. Earth Sci., Roy. Dublin Soc. 1, 115-119.

McKerrow, W.S., Dewey, J.F. and Scotese, C.R., 1991. The Ordovician and Silurian Development of the Iapetus Ocean. Spec. Papers Palaeo. 44, 165-178.

McKerrow, W.S. and Elders, C.F., 1989. Movements on the Southern Upland Fault. J. Geol. Soc. Lond. 146, 393-395.

McLelland, J., Daly, J.S. and McLelland, J.M., 1996. The Grenville orogenic cycle (ca. 1350-1000 Ma); an Adirondack perspective. Tectonophysics 265(1-2), 128.

Oliver, G., Wilde, S.A. and Wan, Y., 2008. Geochronology and geodynamics of Scottish granitoids from the late Neoproterozoic break-up of Rodinia to Palaeozoic collision. J. Geol. Soc. Lond. 165, 661-674.

Pearce, N.J.G. et al., 1997. A compilation of new and published major and trace element data for NIST SRM 610 and NIST SRM 612 glass reference materials. Geostand. News. 21(1), 115-144.

Power, S.E., Ryan, P.D. and Feely, M., 2001. Fluid inclusion studies on the late structural history of the Connemara Dalradian, western Ireland. Abstr. Prog. Geol. Soc. Am. 33(6), 448.

Pudsey, C.J., 1984. Fluvial to marine transition in the Ordovician of Ireland; a humidregion fan-delta? Geol. J. 19, 143-172.

Rainbird, R.H., Hamilton, M.A. and Young, G.M., 2001. Detrital zircon geochronology and provenance of the Torridonian, NW Scotland. J. Geol. Soc. Lond. 158, 15-27.

Rivers, T., 1997. Lithotectonic elements of the Grenville Province: review and tectonic implications. Precamb. Res. 86, 117-154.

Rudnick, R.L., 1995. Making continental crust. Nature 378, 573-578.

Ruhl, K.W. and Hodges, K.V., 2005. The use of detrital mineral cooling ages to evaluate steady state assumptions in active orogens: An example from the central Nepalese Himalaya. Tectonics 24, TC4015(4), doi:10.1029/2004TC001712.

Ryan, P.D., Soper, N.J., Snyder, D.B., England, R.W. and Hutton, D.H.W., 1995. The Antrim-Galway Line; a resolution of the Highland Border Fault enigma of the Caledonides of Britain and Ireland. Geol. Mag. 132, 171-184.

Scott, D.J., 1998. An overview of the U-Pb geochronology of the Paleoproterozoic Torngat Orogen, northeastern Canada. Precamb. Res. 91, 91-107. 
641

642

643

644

645

646

647

648

649

650

651

652

653

654

655

656

657

658

659

660

661

662

663

664

665

666

667

668

669

670

671

672

673

674

675

676

677

678

679

680

681

682

683

684

685

686

687

688

689

Sláma, J. et al., 2008. Plezovice zircon A new natural reference material for U-Pb and Hf isotopic microanalysis. Chem. Geol. 249, 1-35, doi:10.1016/j.chemgeo.2007.11.005.

Stockmal, G.S., Colman-Sadd, S.P., C.E. Keen, Marillier, F., O'Brien, S.J. and Quinlan, G.M., 1990. Deep seismic structure and plate tectonic evolution of the Canadian Appalachians. Tectonics 9, 45-62.

Strachan, R.A., Smith, M., Harris, A.L. and Fettes, D.J., 2002. The Northern Highland and Grampian terranes. In: T.N. H. (Ed.), The Geology of Scotland, pp. 81147.

Suppe, J., 1981. Mechanics of mountain building and metamorphism in Taiwan. Mem. Geol. Soc. China, 4, pp. 67-89.

Suppe, J., 1984. Kinematics of arc-continent collision, flipping of subduction, and backarc spreading near Taiwan. In: S.F. Tsan (Ed.), A special volume dedicated to Chun-Sun Ho on the occasion of his retirement. Mem. Geol. Soc. China, 6, pp. 21-33.

Tanner, P.W.G., Dempster, T.J. and Rogers, G., 1997. New constraints upon the structural and isotopic age of the Oughterard Granite, and on the timing of events in the Dalradian rocks of Connemara, western Ireland. Geol. J. 32, 247-263.

Tanner, P.W.G. and Evans, J.A., 2003. Late Precambrian U-Pb titanite age for peak regional metamorphism and deformation (Knoydartian orogeny) in the western Moine, Scotland. J. Geol. Soc. Lond. 160(4), 555-564.

Tucker, R.D. and McKerrow, W.S., 1995. Early Paleozoic chronology: a review in light of new U-Pb zircon ages from Newfoundland and Britain. Can. J. Earth Sci. 32, 368-379.

Van Staal, C.R., Dewey, J.F., MacNiocaill, C. and McKerrow, W.S., 1998. The Cambrian-Silurian tectonic evolution of the northern Appalachians and British Caledonides: history of a complex, west and southwest Pacific-type segment of Iapetus. In: D.J. Blundell and A.C. Scott (Eds.), Lyell: the Past is the Key to the Present. Geol. Soc. Lond., Spec. Publ., 143, pp. 19-42.

von Huene, R. and Scholl, D.W., 1991. Observations at convergent margins concerning sediment subduction, subduction erosion, and the growth of continental crust. Rev. Geophys. 29(3), 279-316.

Wardle, R.J., James, D.T., Scott, D.J. and Hall, J., 2002. The southeastern Churchill Province: synthesis of a Paleoproterozoic transpressional orogen. Can. J. Earth Sci. 39, 639-663.

Wellings, S.A., 1998. Timing of deformation associated with the syn-tectonic Dawros Currywongaun Doughruagh Complex, NW Connemara, western Ireland. J. Geol. Soc. Lond. 155, 25-37.

Whitehouse, M.J., Bridgewater, D. and Park, R.G., 1997. Detrital zircon ages from Loch Maree Group, Lewisian Complex, NW Scotland; confirmation of a Palaeoproterozoic Laurentia-Fennoscandia connection. Terra Nova 9(5-6), 260-263.

Whitehouse, M.J., Kalsbeek, F. and Nutman, A.P., 1998. Crustal growth and crustal recycling in the Nagssugtoqidian orogen of West Greenland: constraints from radiogenic isotope systematics and $\mathrm{U}-\mathrm{Pb}$ geochronology. Precamb. Res. 91, 365-381.

Williams, D.M., 1972. Ireland, A correlation of Ordovician rocks in the British Isles. Geol. Soc. Lond., Spec. Rpt., 3, pp. 53-59. 
Erosion in the Irish Caledonides - Clift et al.

690 Williams, D.M., 1980. Evidence for glaciation in the Ordovician rocks of western 691 Ireland. Geol. Mag. 117, 81-86.

692

Williams, D.M., 2002. Buried oblique-slip faults in the Irish Caledonides. Geol. J. 37, 135-142.

694 Williams, H., 1979. Appalachian Orogen in Canada. Can. J. Earth Sci. 16, 792-807.

695 Wu, F.Y., Clift, P.D. and Yang, J.H., 2007. Zircon Hf isotopic constraints on the

696 sources of the Indus Molasse, Ladakh Himalaya, India. Tectonics

697 26(TC2014), doi:10.1029/2006TC002051.

698

699 